Comparative ANalysis of Normal Proteus and of their $L$-Forms (per 100 parts dry weight)

\begin{tabular}{|c|c|c|c|c|c|c|c|c|c|}
\hline & Total N & Total $P$ & $\frac{\mathrm{N}}{\mathrm{P}}$ & $\begin{array}{l}\text { Total } \\
\text { lipids }\end{array}$ & $\begin{array}{l}\text { Total } \\
\text { proteins }\end{array}$ & $\begin{array}{c}\text { Total } \\
\text { nucleic acid }\end{array}$ & DNA & RNA & $\frac{\text { RNA }}{\overline{D N A}}$ \\
\hline $\begin{array}{l}\text { Normal Proteus } \\
L \text {-forms }\end{array}$ & $\begin{array}{l}14 \cdot 77 \\
10 \cdot 27\end{array}$ & $\begin{array}{l}2 \cdot 45 \\
2 \cdot 88\end{array}$ & $\begin{array}{l}0 \cdot 60 \\
0 \cdot 36\end{array}$ & $\begin{array}{r}6 \cdot 0 \\
24 \cdot 3\end{array}$ & $\begin{array}{l}73 \cdot 0 \\
58 \cdot 9\end{array}$ & $\begin{array}{r}11 \cdot 59 \\
1.65\end{array}$ & $\begin{array}{l}3 \cdot 28 \\
1 \cdot 45\end{array}$ & $\begin{array}{l}8 \cdot 31 \\
0.20\end{array}$ & $\begin{array}{l}2 \cdot 50 \\
0 \cdot 14\end{array}$ \\
\hline
\end{tabular}

$24.3 \mathrm{mgm}$. lipids per $100 \mathrm{mgm}$. of dry weight. The quantitative importance of this lipidic fraction should be noted. It is much more important than that which can be extracted from normal Proteus (for example, 4-8 per cent). The lipidic fraction contains $2 \cdot 16$ per cent phosphorus.

Analysis of the nucleic acids ${ }^{3}$ in the $L$-forms free from lipids and the acid-soluble fraction shows clearly an amount of deoxyribonucleic acid ( 1.45 per cent of the dry weight of the initial material) greater than that of ribonucleic acid $(0.20$ per cent). The ratio of ribonucleic to deoxyribonucleic acid is thus, for the $L$-forms, just the reverse of that found in normal bacteria. The amount of ribonucleic acid in ordinary bacteria, even in the lag phase (that is, at the time when ribonucleic acid is at its lowest), is generally equal to, or greater than, the amount of deoxyribonucleic acid.

A summary of our results is given in the accompanying table.

Institut d'Hygiène et de Bactériologie,

ROGER VENDRELY ROBERT TULASNE

Faculté de Médecine de Strasbourg,

3 Rue Koeberlé,

Strasbourg.

May 27.

'Tulasne, R., Rev. d'Immunol., 15, 223 (1951); Nature, 164, 876 (1949).

'Tulasne, R., Vendrely, R., Minck, R., and Muller, L., C.R. Acad.
Sci., Paris, 230, 152 (1950).

schneider, W. C., J. Biol. Chem., 161, 293 (1945).

\section{Contamination of Nectar with the Systemic Insecticide 'Schradan'}

RIPPER et al. ${ }^{1}$ have shown that the organophosphorus insecticide, octamethylpyrophosphoramide ('Schradan'), when sprayed on leaves, is absorbed and translocated to other parts of the plant. Metcalf and March $^{2}$ have demonstrated the tolerance to 'Schradan' shown by the honey bee. Using radioactive 'Schradan', containing phosphorus-32, we have examined the possibility of the unchanged insecticide being present in the nectar of flowers and afterwards appearing in honey.

The leaves of white mustard plants (Sinapis alba) were sprayed during July 1952 with an aqueous solution of radioactive 'Schradan' (about $0.75 \mu \mathrm{C}$. per ml.) also containing radioinactive 'Schradan' $(0 \cdot 16$ per cent) and a wetter. A total of $4 \mathrm{ml}$. per plant was applied in five applications over five days. The plants when treated were approximately $1 \mathrm{ft}$. in height and had doubled their size by the end of the experiment (five weeks). All flowers open on the last day of spraying and on the following day were removed, to obviate the possibility of direct contamination of nectar by the spray. Flowers that opened three to twelve days after the completion of the spraying were used as the source of a bulk sample of nectar for assessment of 'Schradan' content. After chloroform fractionation, as recommended by Ripper et al. ${ }^{1}$, radio-assay indicated a concentration of 5.5 p.p.m. of unchanged 'Schradan' in the nectar. Nectar collected over later periods showed lower contents of the unchanged insecticide.

Another test made with borage (Borago officinalis) confirmed that unchanged 'Schradan' could occur in nectar. In this plant the comparable value was $2 \cdot 5$ p.p.m.

Other work has shown that 'Schradan' is not decomposed while in the honey stomach of the bee or in honey during a storage period of ten weeks.

Full details of this work are being published elsewhere.

Seale-Hayne Agricultural College,

G. D. GLynne Jones

Newton Abbot.

W. D. E. Thomas

Research Station,

Long Ashton, Bristol.

Nov. 11.

${ }^{1}$ Ripper, W. E., Greenslade, R. M., and Hartley, G. S., Bull. Ent. Res., 40, $481(1950)$

${ }^{2}$ Metcalf, R. L., and March, R. B., J. Econ. Ent., 42, 721 (1949).

\section{Transmission of Hop Mosaic by Phorodon humuli (Schrank)}

Mosaic disease of hops was first described by Salmon ${ }^{1}$. Later Thrupp ${ }^{2}$, and Salmon and Ware ${ }^{3}$, showed it to be transmissible by grafting. This was followed by the extensive studies of Mackenzie et al.4, who showed that some commercial varieties were symptomless carriers. Growers' observations of spread from carrier varieties to adjacent susceptible hops were confirmed by Keyworth ${ }^{5}$.

It was suspected that insects were responsible for the spread of mosaic, and in 1948 an extensive experiment was carried out to test the ability of the hop-damson aphid, Phorodon humuli (Schrank), to transmit the virus. Eggs of this aphid, laid on Prunus spp. in the autumn, hatch in early spring and, after several wingless generations, winged forms develop which migrate to hop. There follows a succession of asexual wingless generations throughout the summer. Another winged generation occurs which returns to Prunus and produces wingless sexual females. These are fertilized by winged males which develop to maturity on hops and then migrate to Prunus. 3,520 summer wingless $P$. humuli were tested as vectors with short and long feeding periods, using eight different sources of hop mosaic as infectors, but there was no transmission to the 128 indicator plants.

Work was therefore started to find other insects that might be suspected of transmitting hop mosaic. A survey of the insects occurring on hops was made by Paine ${ }^{8}$, and an experiment designed to determine the period during which mosaic spreads. Monthly collections of insects were made at five gardens in which mosaic was known to be spreading. Thirty-five species were recorded in one year and twenty-three in the next; only six species were found in both years. As mosaic had spread in both years it was 